\title{
Sudro Hakimi's Political Strategy in Winning the 2019 Interim Mayoral Election in Nagari Talu
}

\author{
Riko Riyanda \\ Universitas Muhammadiyah Sumatera Barat, Indonesia \\ riyanda.fisip@gmail.com
}

\begin{abstract}
This research aims to describe and identify Sudro Hakimi's political strategy in winning the InterTime Wali Nagari electionin Talu. In this study it was found that Sudro Hakimi's political strategy was effective in winning him over as wali nagari over time. The strategy used is offensive by strengthening the electoral base and expanding the network of voters (conference nagari partisipant) by visiting ninik mamak in villages with priority areas where there are no candidates. Then by using a defensive strategy, namely by keeping voters who are already committed to expressing their support and choice to Sudro Hakimi. The next strategy is a campaign carried out by means of direct friendship to voters by Sudro Hakimi in areas where there are no candidates and friendship by the winning team in areas where the opposing team is based.
\end{abstract}

Keywords: Winning strategy, mayoral election, between time

\section{Introduction}

The Village Head Election (Pilkades) is an instrument in the formation of a modern and democratic government. Where Pilkades is a form of practice of channeling the will of the people in the village area. The village head is directly elected by the people through the Pilkades. So that the village head election process is said to be the original form of democracy and at the same time a characteristic manifestation of the life of Pancasila democracy. (Daeng Sudriwo, 2011: 52)

The inter-time election model has become a new phenomenon in the history of the Pilkades. Where the election of the Village Head can be held through deliberation for consensus or voting based on the results of the Village deliberation. As regulated in Article 45b paragraph (3) of Government Regulation Number 43 of 2014 which states that "The implementation of the election of a Village Head candidate by the election committee through a consensus mechanism or through voting that has been agreed upon by the Village meeting".

According to Surdin, in general, not many people know and understand about Pilkades between times. So far, if there is a vacancy in the village head position, the government appoints an official Village Head until there is a definitive village head through the Village Head Election (Pilkades). Village head elections are not held "temporarily" but are carried out simultaneously. Thus, the village whose "Village Head" is dismissed before the end of his term of office, must wait for the schedule determined based on statutory regulations. (Anang Wahyu Kurnianto, 2016)

Minister of Home Affairs Regulation Number 82 of 2015 concerning the Appointment and Dismissal of Village Heads, in Article 8 Paragraph (3) it is stated, if the Village head resigns due to death, at his own request or due to dismissal, the Village Consultative Body shall report to the Regent/Mayor through the Camat or other designation.

The holding of a Special Village Deliberation for the Interim Village Head Election is regulated in Article 42 of the Minister of Home Affairs Number 110 of 2016 concerning the Village Consultative Body, stating that The BPD holds a special Village meeting for the interim Village Head election. The holding of the Village 
deliberation as referred to in paragraph (1) is carried out to ratify the Village Head candidate proposed by the committee as well as to select and ratify the elected Village Head candidate.

Especially in West Pasaman Regency, Nagari Talu is the first nagari to hold an Inter-Time Nagari Wali Election, after the presence of Law Number 6 of 2014 concerning Villages. The Wali Nagari Talu previously passed away during the 20142020 term. Based on this, there is a remaining term of office of approximately
1.5 years. According to the existing regulations, there is sufficient reason for holding the interim election of the nagari guardian. The holding of the interim Nagari Wali election is a new thing in Nagari Talu.

The Interim Nagari Wali Election held in Nagari Talu was tight and fierce in the competition between candidates. This can be seen from the number of votes between the candidates. Where Sudro Hakimi as the winner only differed by 3 (three) votes from his rival, Nurli Efendi. The following is a list of the votes for each candidate:

\section{Table 1}

\section{Inter-Time Election of Candidates for Mayor of Nagari}

\begin{tabular}{ccc}
\hline Candidate No & $\begin{array}{c}\text { The Name of the } \\
\text { Candidate for the } \\
\text { Guardian of the Nagari } \\
\text { Between Time }\end{array}$ & Candidate Votes \\
\hline 1 & Sudro Hakimi, S.Pd.I & 57 \\
2 & Nurli Efendi, S.Th.I & 54 \\
3 & Firmansyah & 41 \\
\hline \multicolumn{2}{l}{ Data Source: Office of the Mayor of Nagari Talu in 2021 }
\end{tabular}

Sudro Hakimi won the most votes in the election. If you look at his profile, Sudro Hakimi is one of the children of Nagari Talu who is running as a Candidate for the Interim Nagari Wali. He was 33 years old at the time of his candidacy and was the youngest candidate among the two other candidates, namely Nurli Efendi and Firmansyah.

Sudro Hakimi lives in Kampung Melayu Jorong Sei. Clear Nagari Talu. Sudro Hakimi has his last education S.1 Bachelor of Education at the State Islamic High School Batu Sangkar. While in college, he was involved in many organizations, served as General Secretary of the Tsanawiyah Aliyah Muhammadiyah Talu Alumni Association Tanah Datar Branch and was active in the Tanah Datar Branch of Muhammadiyah Student Association and other organizations. This is his main provision to nominate as the Inter-Time Nagari Wali.

\section{Method}

The author uses a qualitative approach, in collecting the necessary data there will be interaction and a direct relationship between the author and the informants who provide information in this research. Qualitative methods use observations, interviews, or document review.(Lexy J. Moleong, 2007: $10)$. The group under study is a sociocultural unit that is natural and interacts with each other individually or in groups.(Sukmadinata, 2009: 49)

This research includes descriptive research, because it aims to describe the circumstances or phenomena that occur in the field. According to Suharsimi Arikunto, descriptive research is a research that aims to describe or explain something, such as circumstances, conditions, situations, events, activities and others. Through qualitative research methods, it is hoped that it will be able to describe Sudro Hakimi's political strategy in winning the election of the Interim Nagari Wali in Nagari Talu.

Steps in qualitative data analysis (Suharsimi Arikunto, 2010: 3) including the following:

1. Data collection

In collecting data, researchers first read field notes and all data both from interviews and documents related to Sudro Hakimi's 
political strategy in winning the interim Nagari Wali Election in Nagari Talu.

2. Data reduction

Reducing data in the form of summarizing, choosing the main things, focusing on the things that are important, looking for themes and patterns and removing unnecessary ones. The research was conducted by examining materials related to Sudro Hakimi's Winning Political Strategy in the Election of Wali Nagari over time. Where the focus of this research is to analyze Sudro Hakimi's Political Strategy in Winning the Interim Nagari Wali Election in Talu.

3. Data Presentation

Presentation of data in qualitative research, can be done in the form of brief descriptions, charts, relationships between categories, flowcharts and the like. So that the research results are presented in the form of a description of data analysis with additional tables, charts and other supporting data. The results of data analysis are presented descriptively, namely by telling and describing what is with the problems studied.

\section{Results and Discussion}

\subsection{Sudro Hakimi's Political Strategy in} Winning the Interim Nagari Wali Election in Talu

Based on the research, it can be described the political strategy used by Sudro Hakimi, so that in the Interim Nagari Wali Election he can win. The strategies are:

\section{Offensive Strategy}

The political strategy used by Sudro Hakimi was a maximum effort to win the Inter-Time Wali Nagari Election in Talu. The political strategy for Sudro Hakimi's victory in the Interim Nagari Wali Election is largely determined by how to influence voters who are delegates from each village which consists of 5 elements, namely the ninik mamak element, the pious ulama element, the clever cadiak element, the bundo kanduang element, the youth element, the representative envoy. farmer groups from 25 villages in Nagari Talu, Voters from Bamus Members and Officers (Pj) Wali Nagari Talu. The number of voters is described in the following table:

Table 2

Number of Voters

Interim Election of Nagari Walis in Talu in 2019

\begin{tabular}{ccc} 
No & Envoy/Element & $\begin{array}{c}\text { Number of Village } \\
\text { Missions }\end{array}$ \\
\hline 1 & Ninik Mamak & 25 \\
2 & Ulama & 25 \\
3 & Smart Outsmart & 25 \\
4 & Bundo Sis & 25 \\
5 & Youth & 25 \\
6 & Farmer's group & 25 \\
7 & representative & 9 \\
8 & Member of Bamus & 1 \\
\hline & Acting Wali Nagari & $\mathbf{1 6 0}$ \\
\hline
\end{tabular}

Data Source: Office of the Mayor of Nagari Talu, 2021 
Based on the data above, the number of voters (participants in the Nagari Deliberations) in the Interim Nagari Wali Election is 160 (one hundred and sixty) people. The 160 people consisted of representatives from 5 elements and one representative from farmer groups from 25 villages in Nagari Talu. This determination is stated in the Bamus Nagari Talu Decree Number 05 of 2019 concerning the Number of Community Elements participating in the Nagari Deliberation. Where the elements have been explained in Article 14 of the Regulation of the West Pasaman Regent Number 13 of 2019 concerning the Interim Election of Nagari Walis.

Sudro Hakimi's participation as an Interim Nagari Wali Candidate in the Interim Nagari Wali Election has received support from various elements, because if you look at his profile, Sudro Hakimi is the youngest candidate among the other candidates. This can be seen in the table regarding the age of the interim Nagari Wali Candidates, as follows:

Table 3

\section{Age of Candidate for Nagari Guardian over time}

In the Interim Nagari Wali Election in Nagari Talu

\begin{tabular}{ccc}
\hline No & Candidate Name & Age (years) \\
\hline 1 & Nurli Efendi, S.Th.I & 38 \\
2 & Sudro Hakimi, S.Pd.I & 33 \\
3 & Firmansyah & 38
\end{tabular}

Source: Office of the Mayor of Nagari Talu, 2021

Based on the table above, it is clear that Sudro Hakimi is the youngest candidate compared to the other 2 candidates. Aside from being the youngest candidate, Sudro Hakimi also has a good track record and experience as an organizational activist such as the Head of Tabligh Division, Branch Manager of Muhammadiyah Sungai Jernih, Chairman of the Youth Branch of Muhammadiyah Talamau, General Treasurer of the Central Leadership of the Talu Muhammadiyah College Alumni Association. In addition, Sudro Hakimi also has work experience as Da'i Nagari Talu, teacher at Madrasah Aliyah Muhammadiyah Talu and Acting Head of Madrasah Ibtidaiyah Muhammadiyah Sungai Jernih, which aroused the interest of voters to choose Sudro Hakimi.

Sudro Hakimi made a strategy to expand voters and a strategy to penetrate voters. Sudro Hakimi's voter expansion strategy is to visit Ninik Mamak directly in each village. His aim was to get support from Ninik Mamak in every village and direct his support to Sudro Hakimi. Where this ninik mamak acts as a voter and assigns an envoy from his village as a participant in the Nagari Deliberation who is also a voter in the InterTime Nagari Wali election.

Based on an interview with Sudro Hakimi, he explained that outside the base, Ninik Mamak was in the villages he had visited. Direct visits to these ninik mamak can increase the number of voters who will vote for Sudro Hakimi. Each time the visit turns out to be a positive response from the ninik mamak. The ninik mamak visited were as follows:

Table 4

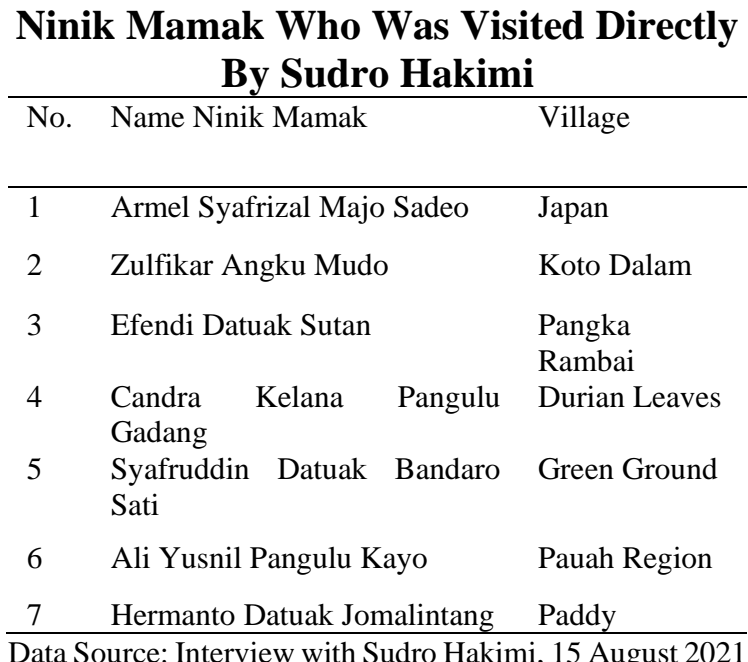
in Talu

All of the ninik mamak visited were very supportive and ready to direct support and invited the Nagari Deliberation delegation from their village to jointly elect Sudro Hakimi in the Talu Nagari Deliberation on June 11, 2019 to elect a Candidate for Wali Nagari Talu Interim. Meanwhile, the expansion of voters in other 
candidate base areas such as in Jorong Merdeka and Tabek Sirah was carried out by the Success Team. A success team formed by representatives of villages and elements in Nagari Talu.

In addition to the strategy mentioned above, there is another strategy used by Sudro Hakimi, namely visiting voters who have been registered by the ninik mamak in each village, especially villages where there are no candidates in the jorong area. The aim is to explore aspirations so that they can be used as Sudro Hakimi's work agenda after being elected. Sudro Hakimi often comes to Jorong Perhimpunan to stay in touch and lobby voters through ninik mamak. Usually the candidate who often visits this voter, the voter will vote for him, especially at the bottom of this association there is no candidate.

Based on the description above, it can be explained that the offensive strategy carried out by Sudro Hakimi was to go directly to ninik mamak which aims to broaden voter support.

The approach taken by Sudro Hakimi is different from that of his political opponents, Sudro Hakimi chooses to work hard to seek support through direct ninik mamak. In the meeting with ninik mamak, Sudro Hakimi did not make any high-level political promises, but if elected he would fight for prosperity in all aspects. In addition, Sudro Hakimi is an energetic young man, has a lot of experience in the organization and an adequate level of education, so he is very appropriate to be chosen as a nagari guardian from time to time.

\section{Defensive Strategy}

In addition to using an offensive strategy, Sudro Hakimi also uses a defensive strategy, namely a strategy to retain voters. A voter retention strategy means that candidates will keep or secure their regular voters and strengthen voter understanding. The candidates will elect or retain loyal voters, and will provide direction or input to voters who are still hesitant in determining their preferred attitude.
The strategy to retain Sudro Hakimi's voters is by not giving grandiose promises to his voters, Sudro Hakimi always takes approaches and gives money as a substitute for transportation for his voters so that the committed voters will stick to their commitments with Sudro Hakimi.

The strategy to keep Sudro Hakimi's voters is to stay in touch with the ninik mamak, thus Sudro Hakimi believes that by establishing good communication with the ninik mamak, it will produce good results, of course, by winning the inter-temporal mayoral election in Talu village. This can be seen from Sudro Hakimi's vote acquisition after the interim village mayor election was carried out, as follows:

\section{Table 5}

Results of Inter-Time Candidate for Wali Nagari Vote

\begin{tabular}{ccc}
\hline $\begin{array}{c}\text { Serial } \\
\text { number }\end{array}$ & Candidate Name & Voting \\
\hline 01 & Sudro Hakimi, S.Pd.I & 57 \\
02 & Nurli Efendi, S.Th.I & 54 \\
03 & Firmansyah & 41 \\
\hline Amount & & 152 \\
\hline
\end{tabular}

Data source: PAW 007 Panlih Model Document, Vote Count Result Certificate, 2021

\section{Campaign Strategy}

Sudro Hakimi's campaign strategy in the Interim Nagari Wali Election in Nagari Talu was carried out in the form of doot to door. Where Sudro Hakimi went directly to the ninik mamak as voters in the InterNational Deliberation. Sudro Hakimi visited niniak mamak in another jorong with the objective for increasing voter support in the interim mayoral election.

The entire winning team is to carry out a campaign strategy from door to door without being limited by space and time. This means that all members of the winning team can do it at any time and it is done to all voters (musyna participants) in the villages in coordination with the ninik mamak.

\section{Conclusion}

Sudro Hakimi's Political Strategy in winning the interim village mayoral 
electionin Talu is an offensive strategy by expanding the network of voters (musyna participants) by visiting ninik mamak in villages with priority areas where there are no candidates. The defensive strategy is to keep voters who are already committed to expressing their support and choice to Sudro Hakimi by providing replacement money for transportation at the time of the Musyna. The next strategy is a campaign carried out by way of direct friendship to voters by Sudro Hakimi in areas where there are no candidates and friendship by the winning team in areas where there are candidates.

\section{References}

Kurnianto, A. W., \& Kusumo, R. A. (2020). Recall on Village Heads Election: An Election Law Reform. Journal of Law and Legal Reform, 1(2), 201-214.

Daeng S. (2011). Principles of Regional Government and Village Administration. Bandung Space.

Moleong, L.J. (2007). Qualitative Research Methods. PT Youth Rosda Karya.

Arikunto, S. (2010). Research procedure a practical approach. Jakarta: Rineka Cipta, 152.

Sukmadinata, N.S. (2009). Educational Research Methods. PT Youth Rosda Karya.

Law of the Republic of Indonesia Number 6 of 2014 concerning Villages.
Government Regulation of the Republic of Indonesia Number 43 of 2014 concerning Implementing Regulations of Law Number 6 of 2014 concerning Villages.

Regulation of the Minister of Home Affairs of the Republic of Indonesia Number 65 of 2017 concerning Amendments to Regulation of the Minister of Home Affairs Number 112 of 2014 concerning Election of Village Heads.

Regulation of the Regent of West Pasaman Regency Number 13 of 2019 concerning the Interim Election of Nagari Guardians. 